\title{
Hong Kong's Elusive Identity: Searching in the Past, Present, and Future
}

\author{
James W. Ellis ${ }^{1}$ \\ ${ }^{1}$ Research Assistant Professor, Academy of Visual Arts, Hong Kong Baptist University \\ Correspondence: James W. Ellis, Research Assistant Professor, Academy of Visual Arts, Hong Kong Baptist \\ University. Tel: 852-3411-8244. Email: jwellis1@hkbu.edu.hk
}

Received: July 27, 2018

doi:10.5539/ach.v10n2p90
Accepted: August 29, 2018

Online Published: August 31, 2018

URL: http://dx.doi.org/10.5539/ach.v10n2p90

\begin{abstract}
Hong Kong is adrift between its British colonial past and its upcoming political reunification with the ancestral Chinese motherland. Hong Kong has endured a prolonged identity crisis in recent years, as it struggles to reconcile conflicts between its transnational worldview and the cultural identity, or Chineseness, of its majority population. A growing wave of nostalgia for the colonial era has frustrated Beijing's efforts to win the hearts and minds of Hongkongers. This essay analyzes how Hong Kong's distinctive local character is reflected in several socio-cultural arenas: the heritage industry, filmmaking, efforts to preserve historic structures and intangible heritage, public education, and tourism. With reunification on the horizon, Hongkongers want to assert an independent cultural identity but still seem to exist at the "intersection of different spaces".
\end{abstract}

Keywords: Chineseness, Culture, Heritage, Hong Kong, Identity, Mainland China

\section{Introduction: Nostalgia for Colonial Hong Kong}

Chen Zuoer apparently could not believe his eyes. It was July 1, 2012, and Chen, a deputy director of mainland China's Hong Kong and Macau Affairs Office, was watching news coverage of a protest in Hong Kong (Note 1). Hundreds of thousands were in the streets demonstrating against the Chinese government's suppression of human rights and its growing influence on Hong Kong politics and society (Figure 1). The protest coincided with the Communist Party of China's celebration of the fifteenth anniversary of the 1997 transfer of Hong Kong's sovereignty from the United Kingdom to China ("the handover"). The handover, in the eyes of some, signalled the end of the British Empire (Note 2). Chen said he was "heartbroken" to see protestors carrying the British Hong Kong flag and chanting anti-Chinese slogans. Chen wondered why Beijing still had "fail[ed] to win the hearts and minds of Hongkongers" and why there was a "growing wave of nostalgia for the colonial era among some Hong Kong people" (Cheung 2012).

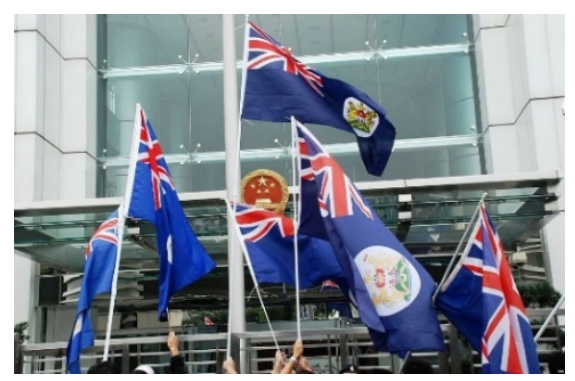

Figure 1. Protestors Wave Hong Kong's Colonial Flag Outside the China Liaison Office in Hong Kong Wikimedia Commons

Johannes Hofer, a seventeenth century Swiss physician, invented the term nostalgia by fusing the Greek words nostos (which means a homecoming) and algos (meaning pain) (Note 3). Nostalgia is an intense, bittersweet, generally pleasurable (Tierney, 2013), desire to return to a place one perceives as her/his past home. Many contemporary Hongkongers express nostalgia for Hong Kong's colonial past, including some who are too young 
to remember anything before the city's 1997 handover (Note 4). Children construct positive fantasies when they pretend play (Note 5). Even though young Hongkongers' memories of their past home might only reflect a "likely world" (Note 6), nostalgia provides a comforting "sense of home" anyway, which can strengthen the bond between people and places (Ross, 2015). At the time of the handover, some residents saw Hong Kong's transfer from Britain to China as an existential threat to the city's identity. When a perceived past home is in danger of disappearing, people grow anxious, fearing they will be disconnected from their past self-a condition psychologists call self-discontinuity (Sedikides, 2015, 52-61). Colonial nostalgia has helped some Hongkongers offset this anxiety.

Whatever its causes, colonial nostalgia can be counterproductive, distorting the past and directing attention away from the future (Harrison, 2010, p. 18). Chen Zuoer rightly wondered why Hong Kong's ethnic Chinese residents would long for a return to the era when Hong Kong was a British Crown Colony (1849-1997). During that period, the city's British and Chinese communities were not always on the best of terms or on an equal social standing. In fact, in much colonial writing British Hongkongers arrogantly presented themselves as "benevolent colonists, racially superior to the Chinese" and early Chinese writers "did not flinch from describing Western barbarians as "round-eyed, long-nosed foreign devils" (White, 1996, p. xiv). Nostalgia is "no stickler for [such] details" (Lucado, 2012, p. 44).

Hong Kong activists embrace British colonial symbols to protest against what they perceive to be the mainland Chinese government's "interference in [local] politics, education and media" ("In pictures", 2017). Forty-year-old activist and artist, Alice Lai, for example, heads a small protest group called the Hong Kong-U.K. Reunification Campaign. Lai regularly waves a British Hong Kong flag at political rallies. "Hong Kong and the U.K. coexisted in a proven, well-functioning system for close to two centuries. ... China is simply unfit to be governing Hong Kong - it's a different way of thinking, a different way of life", says Lai ("In pictures", 2017). John Carroll teaches history at Hong Kong University. Carroll thinks such attitudes reflect an over focus on the city's prosperity in the nineteen-eighties and -nineties, and fails to take into account harsher colonial phases, such as left-wing bombings and protests during the nineteen-sixties, communist riots during nineteen-fifties, and the painful Japanese occupation of Hong Kong following Britain's surrender on Christmas Day 1941 ("In pictures", 2017). Historical amnesia, when people see only what they want to see, is nostalgia's more troublesome relative ("The Danger of Historical Amnesia", 2002).

\section{Hong Kong's Heritage Industry}

Heritage refers to the cultural characteristics a particular society receives from the past and still considers important. Heritage is an inheritance, linking one generation to the next through evolving, transformative processes (Note 7). Heritage "acts as an historical record and tangible expression" of identity that has the potential to connect past, present, and future generations to a shared "collective history" (Chu \& Uebegang, 2002, 6). In general, historians and heritage scholars work in unison, offering ways to interpret history and proposing what might, or should, be done with the past (Moody, 2015). However, there is not always a perfect union between historical accuracy and heritage formation. People often see only part of the picture, motivated or constrained by their own concerns and experiences. Collective historical amnesia (or memory loss) plays an important part in defining heritage.

When China resumed sovereignty in the late nineteen-nineties, Old Hong Kong seemed to be slipping away (Note 8). Long-time residents began documenting and interpreting what made their city interesting and historically distinctive, because they sensed the threat of cultural obsolescence. The late-nineties outpouring of memoirs, reminiscences, visual histories, and exhibitions spawned Hong Kong's (still flourishing) "heritage and memory industries" (Ng, 2010, p. 45). Heritage and culture can be used in the service of nation building. The Hong Kong Heritage Museum opened in 2000 and several smaller institutions devoted to local culture were established around the same time (Ng, 2010, p. 45). In his official policy address of 1999, Hong Kong's Chief Executive, Tung Chee Hwa stressed the importance of preserving the city's "unique cultural history" to help "establish our identity" and "attract tourists" (Policy Address, 1999).

The Hong Kong Museum of History's permanent exhibition, "The Story of Hong Kong", opened in 2001. The exhibition uses reconstructions of colourful local festivals and life-size dioramas of shop interiors and public housing flats to represent daily life in the colonial city (Figure 2). The popular reconstructions and dioramas are not real (not the actual shops or flats), but they are so appealing that they become "hyperreal" (Hendry, 2016, pp. 524-6). They fulfil what Italian semiotician Umberto Eco called "daydream demands" (Eco, 1986, pp. 39-48), giving museum visitors sanitized versions of harsher realities (Note 9). Unlike the pursuit of history, official forms of heritage are often concerned with reimagining and "re-packaging the past for some purpose in the 
present" (Harrison, 2010, p. 10). The history museum's narrative replaces historical accuracy with fantasy, producing a longing "for an idealized space, which substitutes as the "true past"” (Ng, 2010, pp. 50-51). "The Story of Hong Kong" portrays and promotes a few examples of the city's idiosyncratic past as tourism products (Note 10), without disturbing visitors with troubling social, political and economic problems.

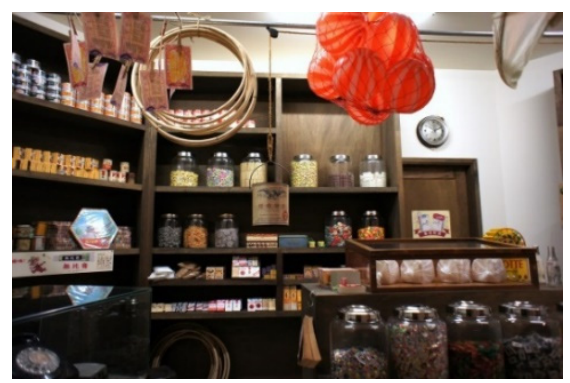

Figure 2. Grocery Store in Hong Kong, 1960s, "The Story of Hong Kong” Wikimedia Commons

Heritage tourists can also learn about Hong Kong's former physical identity outside the museum. Even though the city has gone through a "decolonisation process" for many years (Sharp, 2013), British-era buildings, building fragments (or ruins), symbols, and relics remain scattered throughout Hong Kong. Like other Asian cities and countries that have accepted the colonial legacy as part of their local heritage, Hong Kong has taken steps to protect Western elements (Logan, 2002). It is still possible, by consulting historical resources, photographs, and nostalgic books, to take a postcolonial Grand Tour of colonial Hong Kong (Ellis, 2017, 209-32). However, many demolished colonial structures now exist only as "invisible monuments", alive today in the form of "spectral monumentality", as old images and films shared on internet sites (Grace, 2007, 468). Digitized photographs and films play an important role in embodying the "historical memory" of Hong Kong, which is itself "characterized in many ways as image" (Grace, 2007, 468). Urban explorers and tour guides have begun surreptitiously visiting and photographing the interiors of Hong Kong's bygone, dilapidated sites in danger of demolition, such as old factories, cinemas, and apartment blocks. They hope to document a part of Hong Kong's identity that is quickly disappearing (Note 11).

\section{Selective Memories}

Hong Kong's nostalgia industry flourishes in tourism promotions. The Hong Kong Tourism Board, for instance, has arranged for a restored junk to sail across Victoria Harbour before Hong Kong's famous skyline. This illustrates for tourists a focused narrative: that the city transformed from a barren fishing village to one of the world's most prosperous financial centres (Dapiran, 2017) (Figure 3). How people remember the past affects what they preserve and emphasize. People with selective memories tend to focus on the past's happier moments and exclude realities that are more unpleasant. This can lead to selective preservation and the "disappearance of history" (Abbas, 1997, p. 66). When historical realities disappear-whether due to limited memories or deliberate forgetting - heritage scholars and preservationists have opportunities to create new, more-focused narratives (Abbas, 1997, p. 14). The junk before the skyline archetype, for example, references 1) precolonial Chinese Hong Kong (the junk) and 2) Postcolonial Hong Kong's contemporary position as one of China's most successful global cities (the skyline). The colonial interlude has disappeared.

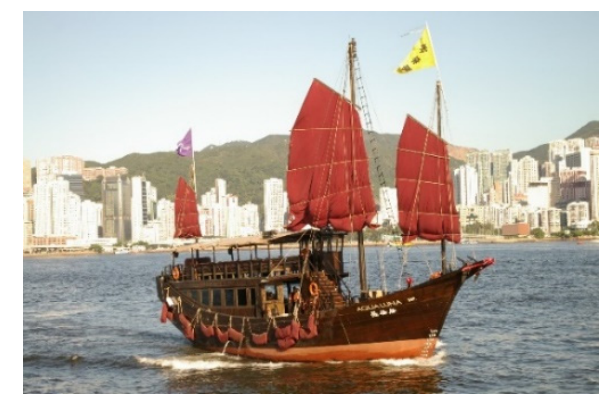

Figure 3. A Familiar Archetype Wikimedia Commons 
Contemporary Hongkongers and the nostalgia industry may wish the colonial era's unpleasant realities could disappear. British colonialism depended on the "devaluation of local culture and identity" and systematic exploitation of the local population (Abbas, 1997, p. 66). Westerners attempted to justify discrimination and exploitation by stressing improvements that came with colonization. Russian playwright, Anton Chekhov visited Hong Kong in 1890 and was impressed. When he returned to St. Petersburg, Chekhov told a friend,

[In Hong Kong there are] nine roads, horse-trams, a railway up the mountain, museums, botanical gardens; wherever you look you see the Englishman's most tender concern for their employees ... [I] was annoyed to hear my Russian companions cursing the English for exploiting the natives. I thought: yes, the English exploit the Chinese ... but they do give them roads, piped water, museums, Christianity, you [Russians] exploit them and what do you give them? (Rayfield, 1997, p. 234).

Chekhov was a Russian visitor to the city, yet he articulated a commonly held view among British colonists, who saw themselves as the upper class, yet benevolent toward the local Chinese populace. Today's historians and heritage scholars must decide what to do with the colonial legacy of Hong Kong, as the city is absorbed into modern China. There may be pressure to manipulate history in response to changing political conditions and globalization. Pressures to substantiate national narratives may overwhelm local concerns. There are many signs Hong Kong will be much more similar to other Chinese cities in the future than it is today. Before that happens, a window is open for historians and heritage scholars to ask and propose answers to fundamental questions about Hong Kong's past. Who were the city's cultural belongers? (Note 12). Which historical structures deserve to be preserved? Did the British colonizers contribute to the city's intangible heritage?

\section{Hongkongers and the Hong Kong Identity}

Staying as I am, one foot in one country and the other in another,

I find my condition to be very happy, in that it is free.

-Rene Descartes, Letter to Elisabeth of Bohemia, July 1648.

Before the Second World War, Hong Kong's Chinese community consisted mainly of migrants, who intended to return to the mainland after earning sufficient money. They did not have a distinct Hong Kong identity, but had much more in common with Chinese mainlanders than with Hong Kong's non-Chinese, expatriate community (Tsang, 2007, p. 180). After the war, many younger, locally born and raised ethnic Chinese began to see Hong Kong as their home (Note 13). They considered themselves hèung góng yàhn (香港人), an ambiguous term that roughly translates as Hong Kong Chinese, yet refers more to residents than to "a people" (Turner, 1995, p. 22). For much of the colonial era, the Chinese and Western expatriate communities held a general antipathy and aloofness toward each other. Then, with Hong Kong's rising success and affluence during the nineteen-eighties, the aloofness was replaced with a "tacit mutual acceptance of parallel existence" (Tsang, 2007, p. 194). The local Chinese community did not include or exclude the British from "we, the people of Hong Kong"; rather they accepted them as fellow Hong Kong belongers, with whom they shared a few core values (Tsang, 2007, p. 194). Over time, a local lifestyle displaced many traditional cultural connections as the basis for personal identity among hèung góng yàhn (Turner, 1995, p. 24).

Like the Chinese community before the Second World War, Hong Kong's Westerners were mainly expatriates, stopping temporarily at a distant port and cultural crossroad. In 1914, British travel journalist, Mary A. Poynter wrote, "go you east or west, go always you must to Hong Kong, for it is a part that lies ever in your path, not obtrusively, but as a calling-place on your way to somewhere else" (Poynter, 1921). Hong Kong was important logistically, initially as an entrepôt for opium from British India and for the trade of exotic, oriental goods, such as silk and porcelain (Note 14). Ackbar Abbas referred to Hong Kong as Britain's last emporium (Abbas, 1997, p. 3), a place where people are always passing through and everything has a limited shelf life.

Westerners have always thought of Hong Kong as a "good place to do business" and an interesting place to visit (Turner, 1995, p. xvi), like an immense Chinatown. There are many Chinatowns around the world with various defining characteristics. Some are segregated communities (or Chinese enclaves) composed of residences and businesses, "governed by interlocking associational social networks" and an "overall community organization". Other Chinatowns are simply "places [with] Chinese populations and Chinese shops" (Wong, 2013, p. 2). Some Westerner visitors see these characteristics in Hong Kong. As they pass through the city, Westerners admire its exotic features, which they understand to be generically Chinese, without paying much attention to the Western physical and cultural modifications" (Wei \& Li, 1998, p. 15).

Is there a Hong Kong identity? A city must project an attractive and distinctive personality to lure visitors for business and pleasure. Determining what makes Hong Kong unique has been a difficult task, however, because it 
sits on the edge of the motherland of a great, ancient Eastern civilization, yet its modern history was a British creation, in the British tradition (Wei \& Li, 1998, p. 14). Two of the world's "stronger, more clearly defined cultures" buried Hong Kong's identity under their distinct interests (Cody, 2002, p. 205), and the city has struggled to stand on its own. To draw visitors, Hong Kong's tourism industry fell back on a somewhat superficial, appealing East meets West trope. Even after Mao Zedong, in the mid-twentieth century, closed the East of the People's Republic of China ("PRC") to most outsiders, Westerners were still drawn to the East of Hong Kong (Ng, 2010, p. 54).

For much of its history, Hong Kong was a haven for mainland refugees and workers fleeing from troubles in China or seeking economic opportunities. Coming and going from the Guangdong province, which borders Hong Kong, was relatively easy until the PRC emerged victorious from the Chinese Civil War. Chairman Mao's triumph in 1949 caused a flood of new refugees to pour out of China into Hong Kong with no hope of ever returning. The city's population surged from around 500000 in 1945 to more than 2 million in 1950. Businesses and individuals also transferred massive amounts of capital from banks in Shanghai and Beijing to banks in Hong Kong. These demographic and economic changes set the stage for late-twentieth century re-evaluations of the British colony's identity.

An "import mentality" encouraged Hongkongers to see culture as coming from somewhere else (Abbas, 1997, pp. 6-7). Authentic Chinese culture belonged to the mainland or perhaps to Taiwan (Note 15); colonial culture belonged to the British. Even the Cantonese dialect, which sets Hongkongers apart from mainlanders, who use Putonghua-Mandarin, originated in the Guangdong province. Indeed, the terms Hongkonger and Hong Kongese, which distinguishes local residents from mainlanders, only came into use during the decade of the handover (Note 16). Awareness of a special local identity and culture is a recent phenomenon.

Cities with large populations, of course, are never static. They progress and transform as local and transnational forces converge (Amrith, 2014). Hybrid Hong Kong, however, has existed in a permanent state of "in-betweenness" (Erni, 1998, 57), constantly moving on to a major new phase. It first morphed from a distant Chinese imperial outpost into a distant British imperial outpost. Now it is in a state of limbo under the fleeting "one-country, two-systems" policy, which allows Hong Kong to operate under a capitalist system until 2047, while mainland China maintains a socialist system. Because Hong Kong is a site of continuous transition, its unique identity remains elusive.

Beginning in the colonial era, a progression of short-lived tourism slogans tried to encapsulate the city's essence. Early slogans included "Riviera of the Far East", "Pearl of the Orient", and "Europe in China" (Note 17). Today Hong Kong brands itself as "Asia's World City". It is a welcoming description, in the positive spirit of contemporary globalization. Around the world, cities have begun creating identities "to promote an ethos of urban hospitality", presenting themselves as "sanctuary, cosmopolitan or global cities" (Amrith, 2014). "Asia's World City" stresses Hong Kong's importance as a global crossroad without referencing its colonial heritage or its friction with mainland China.

\section{Filmmaking}

Filmmaking, like a tourism slogan or city brand, is a powerful means to create and enforce identities (Note 18). Colonial-era films depicted and typified Hong Kong's inhabitants in differing ways. The British colonial government produced films that projected positive messages of a harmonious, hierarchical society to local and overseas audiences. Conversely, Hong Kong's local Chinese filmmakers, in particular Bruce Lee, spoke to the same audiences about Chinese ethnic nationalism and inequalities in the colonial system.

The Hong Kong Film Unit (HKFU, 1959-73) oversaw official British colonial filmmaking. During its first few years, the HKFU primarily produced short, black and white instructional films and a newsreel entitled Hong Kong Today, both in English and Cantonese. The newsreels presented new construction projects, and provided information on public safety, health, education, and welfare. Hong Kong Today was shown in the city's sixty-eight cinemas before the main feature presentations and independently in public resettlement housing estates (Aitken \& Ingham, 2014, p. 89). The newsreel was an effective means of "communicating information to the local public and helping develop a sense of a more integrated Hong Kong identity" (Aitken \& Ingham, 2014, p. 89).

The HKFU's first world-wide release, a feature entitled This is Hong Kong, was produced in 1961. This is Hong Kong belongs to the genre of Empire Cinema. It attempts to justify colonialism, in part, by showing how Hong Kong's traditional Chinese residents benefited from their modern British government. At the beginning of the film a plane lands in Hong Kong and an unseen narrator takes the new visitors on a selective tour. The narrator is not shown, but his voice is kind, wise, and authoritative. The narrator presents Hong Kong as a flourishing 
modern city and international business center. Although the paternalistic narrator rarely mentions China, he does insist that colonial guidance and economic modernisation can solve problems posed by Chinese immigrants, or "the population", such as unemployment and inadequate housing (Aitken \& Ingham, 2014, p. 92). When it is portrayed, Chinese culture is an exotic precolonial remnant for viewers to enjoy. Chinese residents are shown working contentedly in factories or on farms along the "problematic" Chinese border, which the narrator describes as "the frontier between two different ideologies which divide the world" (Aitken \& Ingham, 2014, p. 94). This is Hong Kong suggests British social and economic advances will insulate Chinese residents from external dangers. The film's messages embodied the city's identity for many Westerners during its late colonial period.

Hong Kong's popular cinema has had a long, successful history, beginning in the silent era and booming in the nineteen-eighties when only Hollywood and India's Bollywood produced more feature films. The early-seventies saw the emergence of Hong Kong's most famous international cultural icon, martial arts movie star Bruce Lee. Unlike This is Hong Kong, Lee's films were meditations on Chinese culture in the colonial age and they appealed to Chinese viewers around the world.

Bruce Lee produced his martial arts films in the wake of a widespread decolonization of East Asia (Note 19), and at a time when Hong Kong was beginning to assert its distinctive personality. Lee's film narratives dealt with the issue of Western colonial exploitation and emphasized Chinese ethnic (rather than political) nationalism (Kato, 2005). His clever Chinese heroes used cultural advantages and raw physical power to triumph over non-Chinese adversaries and "foreign imperialist" villains (Foster, 2007). Chinese brains and brawn, rather than mainland Chinese politics, stood as the "positive counterpoint to the villainy of [Lee's] colonial oppressors" (Wallis, 2011). Lee's characters were like many Hongkongers during the nineteen-seventies, divided between the East and West but fighting for a presence.

In his last film, Game of Death, Lee plays Billy Lo, a Hong Kong martial artist who must ascend to the top of a pagoda, where a criminal syndicate has stashed away a mysterious treasure. At each of the pagoda's levels, Lo successfully fights past a new non-Chinese challenger. Each challenger has a unique fighting style: Filipino master Dan Inosanto uses an Eskrima technique, Korean master Ji Han-jae employs Hapkido methods; and finally $(2.18 \mathrm{~m}$. tall) African-American Kareem Abdul-Jabbar fights Lo in the Jeet Kune Do style. Billy Lo defeats them all.

In the Game of Death fight scenes, Bruce Lee wore his iconic yellow jumpsuit, which was not associated with any known martial arts garb. The yellow jumpsuit was significant, however, in a semiotic sense as a "coding of a transnational identification of "Chineseness" (Bowman, 2009, p. 155). Lee's ethnic messages appealed to audiences around the world, including young Chinese-Americans facing discrimination in the United States (Yip, 2015). According to journalist Yonden Lhatoo, "Bruce Lee changed the derogatory perception in the West that Asians were mostly a faceless mob of timid little people to be pitied or pushed around. He gave us respect. [...] He gave us 'face' - dignity and pride in the social context that Asian people understand so well" (Lhatoo, 2015). If the HKFU's This is Hong Kong represents a Western view of colonial Hong Kong and its Chinese residents, the characters in Bruce Lee's films represent an emerging Hong Kong identity founded on Chinese ethnic nationalism.

\section{Architecture}

Filmmaking constructs and reinforces identity, and architecture can serve a similar purpose. Surviving architectural structures that were culturally significant in the past link the experiences of successive generations. They connect people to past societies and identities, informing them about where they come from (Sedikides, 2015; Ashworth, 2011), and who they are. When cities fail to preserve their built environments and local culture, they can change into indistinguishable modern metropolises. Residents then feel separated from the past, a sense of "placelessness" (Chu \& Uebegang, 2002, 6).

Much of Hong Kong's older built environment is lost. Allied bombing destroyed over 25,000 buildings during the Second World War. In the late nineteen-forties, as mainland refugees flooded into Hong Kong, city planners razed older neighbourhoods to build public housing, schools, markets, and hospitals. More recently, many significant mid-twentieth century structures were demolished to make way for new redevelopment and reclamation projects (a process that creates lands from offshore areas) (Note 20). The city's contemporary urban landscape bears little resemblance to the living environments of previous generations.

The Antiquities and Monuments Office ("AMO") is the government body responsible for preserving Hong Kong's historic structures, which are reflections of the city's "cultural identity and continuity" (Antiquities and Monuments Office, 2018, Built Heritage). When China resumed control over Hong Kong in the 
nineteen-nineties, the AMO conducted an evaluation of its surviving built environment. Nearly 200 buildings received a Grade 1 Status, meaning they would be preserved "if possible". An additional 117 buildings and sites were designated as Declared Monuments, meaning the government could prevent or limit their alteration. Unfortunately, the AMO took a narrow view of cultural identity, failing to recognize that village houses, tenement buildings, and other vernacular architecture contained heritage value (Chu \& Uebegang, 2002, 8). Preservation efforts focused on traditional Chinese temples and colonial British government and military structures. What the AMO chose to prioritize and protect helped define Hong Kong's identity for both outsiders and locals. The AMO selections reminded Hongkongers what of their past was officially worth remembering, and what the government deemed appropriate to pass on to their children. These decisions were made under the supervision of a new government entity, the People's Republic of China.

Considering Hong Kong's Chinese past, present, and future, the list of Declared Monuments contains several historic discontinuities, including the British Army's Lei Yue Mun barracks. During the eighteen-nineties, the barracks housed soldiers protecting Hong Kong Island and Victoria Harbour from mainland Chinese forces (Note 21). Three other Declared Monuments belong to an earlier, pre-colonial period. Tung Lung Fort (ca 1720), Fan Lau Fort (1729) and Tung Chung Fort (1832) were Chinese imperial strongholds built on Hong Kong's outlying islands, predating the British colonial era (Note. 22). The ruins of the old forts remind Hongkongers of their Chinese past and suggest Hong Kong's current position on China's southeastern territorial frontier. The old forts represent historic and cultural continuity.

Hong Kong is the most crowded city in East Asia (Smith, 2017). The constant need for new infrastructure and residential development has resulted in the loss of historic landmarks and buildings. In the process, Hong Kong has lost part of its cultural heritage and part of its "collective memory" (Pang, 2017). Conservationists have become more vocal in their opposition in recent years. A turning point came in 2006, when the Hong Kong government announced it would demolish the famed Star Ferry Pier to make way for a new roadway. Although demonstrators held loud public protests and staged sit-ins, demolition crews finally destroyed the pier during the middle of the night. Public outcry caused the government to change direction and find new ways to preserve, revitalize, and reuse heritage buildings (Note 23). In an age of global urban homogeneity, reusing local historic structures helps differentiate Hong Kong from other cities.

The revitalization of Haw Par Mansion is an exemplar of how Hong Kong finds ways to fuse its past and present identities, and emphasize its Eastern and Western heritages. Aw Boon Haw was a Burmese-born Chinese entrepreneur who became wealthy marketing Tiger Balm, a popular pain relieving menthol ointment. Aw built the Haw Par Mansion in the nineteen-thirties in Hong Kong's Tai Hang neighborhood. The mansion is a prime example of the Chinese Renaissance architectural style (Note 24). Adjacent to his mansion, Aw opened one of Hong Kong's first theme parks, Tiger Balm Gardens, which featured an eclectic mixture of French and Chinese landscaping, monumental concrete sculptures, and a seven-story Tiger Pagoda (Note 25). The theme park was immensely popular, and the pagoda became a symbol of Hong Kong Island (Note 26). Eventually, the park and pagoda fell out of favor and were demolished to make way for a massive housing complex. The mansion survived, however, and passed to the government for preservation through a revitalizing partnership scheme. The mansion will soon reopen as a music conservatory for Western and Chinese music and the main entrance hall will be an exhibition area highlighting the cultural and social significance of Haw Par Mansion and Tiger Balm Gardens (Tomlinson, 2016).

The Tiger Pagoda is gone, but it lives on in vintage photographs and tourism posters. The pagoda joined a small set of visual motifs that defined Hong Kong for outsiders, such as junk boats sailing in front of the skyline, men pulling rickshaws, and women wearing cheongsam dresses. The American illustrator, David Klein created an iconic, jet age tourism poster for Howard Hughes' Trans World Airlines, which includes a familiar checklist of cultural clichés (a dragon, a junk, and the pagoda) (Klein, 2018). Klein's image also features an interesting juxtaposition: a male British colonial judge, wearing a curly-locked formal wig, leers at a well-known female Chinese opera character named hua dan (花旦). The hua dan character is a teenaged girl with a lively, innocent personality (Note 27). The artist's juxtaposition references a common trope: a Westerner contemplating the East as something to consume. The British colonial judge also brings to mind Anton Chekhov's notion that the colonizers exploited Hong Kong's Chinese population, yet offered improvements, such as the British legal system and the rule of law. The hua dan figure, on the other hand, embodies Westerners' fascination with a generic, oriental Hong Kong. The East-West duality-contrasting a modern, orderly Britain and an exotic, traditional China—attracted jet age tourists. 


\section{World History and Chinese History}

In addition to filmmaking and architecture, public school textbooks expose and shape public attitudes. Textbooks show what governments want people to think and what many people actually do think about their society. Direct or indirect governmental influence on content reveals ideology. Hong Kong's history textbooks and curricula, like arguments over the Star Ferry Pier and other heritage sites, have become cultural battlegrounds in recent decades.

The city's recovery after the Second World War was impressive. The war and its aftermath devastated both the global economy and Hong Kong's economy. Japanese forces occupied the city from 1941-45, disrupting trade and factory production, and casting local residents into poverty. When Japan surrendered, it was not clear Hong Kong would remain a British colony (Note 28). Only after British Admiral Cecil Halliday Jepson Harcourt sailed into Victoria Harbour in a Royal Navy cruiser and formally accepted the Japanese surrender on 16 September 1945 was British sovereignty re-established. A few months later, the colonial government lifted provisional controls and free trade resumed (Carroll, 2017, pp. 123-5, 129). During the nineteen-fifties and -sixties, the government subsidized industry, invested in infrastructure, implemented a compulsory education program, and made tax and regulatory policies more attractive to outside investors and corporations. Hong Kong became a global leader in manufacturing and exporting, and later diversified into financial services (Note 29). Because of its economic productivity, by the nineteen-seventies, Hong Kong-along with Singapore, Taiwan, and South Korea - was known as an Asian Tiger (Note 30).

Public school textbooks during the nineteen-sixties fostered a sanitized image of Hong Kong. Textbooks, along with tourism publicity and public information campaigns, described the city as an "industrious, international metropolis" led by a "progressive, modern community" (Turner, 1995, pp. xvi, 22). Colonial textbooks of the period presented Hong Kong as a safe and accommodating place to visit and conduct business, unlike mainland China, and emphasized social harmony, respect for the law, and the city's "conflict-free development" (Bray \& Lee, 1993, 543, 549). It was an attractive image for students and outsiders, but did not reflect the city's social tensions or economic inequalities. During the nineteen-eighties, Hong Kong's public school textbooks began encouraging local students to take pride in their city's status as an economic tiger.

Hong Kong's Curriculum Development Committee/Council (“CDC") introduced a world History syllabus for secondary schools in 1983 that contextualized the city as a progressive ideal in the "development of civilizations worldwide" (Kan \& Vickers, 2002, 12). The emphasis was on economic prosperity and the city's global significance. In 1990, the CDC introduced a new Chinese History syllabus that had a different emphasis: "moralising nationalism". Chinese History students learned to differentiate "good and bad" behaviour by studying Chinese "moral exemplars", who lived sincerely, in accordance with a "conservative, traditionalist vision of Chinese culture and values" (Kan \& Vickers, 2002, 12, 24). Legends and historic anecdotes encouraged students to serve China whole-heartedly and protect "the interests of the national people" (Kan \& Vickers, 2002, 22). When the new Chinese History syllabus mentioned events in Hong Kong, it referred teachers to "contemporaneous developments in China. Thus, Hong Kong [was] seen exclusively as part of China" (Kan \& Vickers, 2002, 27). Hong Kong's first Chief Executive after the handover, Tung Chee Hwa announced in his first policy address "We will incorporate the teaching of Chinese values in the school curriculum and provide more opportunities for students to learn about Chinese history and culture. This will foster a stronger sense of Chinese identity in our students" (Policy Address, 1997).

During the decades following Tung Chee Hwa's address, many feared the Hong Kong government, bowing to pressure from Beijing, wanted to politicize how history was taught in public schools. Between 2007 and 2012, Hong Kong's Education Bureau tried to incorporate National Education into history teaching (Liu, 2012). National Education stressed national identity awareness and Chinese patriotism. Many Hongkongers opposed the curriculum, believing it was tantamount to patriotic indoctrination that would "brainwash" children's minds with pro-mainland propaganda (Lai, 2012). Following prolonged street protests, hunger strikes, and social unrest, the government shelved the plan indefinitely. While Hongkongers have a reputation for apathy, they are still vocal when they feel their identity is being manipulated by outside forces. The Parents' Concern Group on National Education now monitors Hong Kong's public school textbooks and teaching plans for signs of mainland Chinese political and social biases. It seems Hongkongers want their children to learn traditional Chinese values, but are leery of mainland political messages.

\section{Intangible Heritage and Mainlandization}

Hongkongers and mainlanders share the inheritance of China's intangible cultural heritage. Cultural heritage is not limited to buildings or objects in museums; it includes traditions handed down from predecessors, such as 
folklore, performance arts, social practices, rituals, festivals, crafts, and nature and religious beliefs (UNESCO, 2018). Intangible cultural heritage transmits treasured knowledge and skills and has tremendous social value. Chinese communities worldwide, regardless of political differences and borders, recognize this common tradition and inheritance (Note 31).

In 2014, Hong Kong's Intangible Cultural Heritage Office (ICHO) compiled a list of 480 items that have special local significance. The items were placed into five categories: 1) performing arts, 2) social practices, rituals and festive events, 3) knowledge and practices concerning nature and the universe, 4) traditional craftsmanship, and 5) oral traditions and expressions. In 2017, the ICHO released a shorter "Representative List" of Hong Kong's intangible cultural heritage, comprising items of particularly "high cultural value, with an urgent need for preservation" (Intangible Cultural Heritage Office, 2018). The intangible heritage lists differed from the AMO's selection of [tangible] Declared Monuments and historic buildings. The intangible lists did not include any British or Western items. The inference was that Westerners had left a mark on Hong Kong's physical landscape, yet had not left a mark on the city's intangible heritage, which comes entirely from the mainland or local Chinese traditions. However, this is a problematic inference. The local population did not live in a cultural vacuum. Furthermore, there were vast differences between the Chinese society that endured the internal upheavals of the Great Leap Forward (1958-62) and Cultural Revolution (1966-76) and Hong Kong's cosmopolitan, capitalist society.

It is true that a very old heritage intertwines mainland Chinese and Hongkongers. Waves of mainland immigrants came to Hong Kong during the colonial era and millions are residents now. However, since the transfer of sovereignty in 1997, many Hongkongers have grown anxious about losing their city's idiosyncratic qualities, anxious about political and social mainlandization. Nevertheless, according to Chung Kim-wah, a social scientist at Hong Kong Polytechnic University, "being a Hongkonger does not mean one has to forfeit the cultural identity of being Chinese" (Hong Kong residents, 2016). Families with strong mainland roots have grown and prospered in Hong Kong. A second-generation Hongkonger, whose grandfather came from the mainland in the nineteen-seventies, said,

Unless you are among the indigenous inhabitants of the New Territories [along the Chinese border] whose roots in Hong Kong go back for centuries, most of our ancestors came from somewhere on the mainland. ... If you ask a Hongkonger where their ancestral hometown is, chances are that they will give the name of a mainland province. In other words, our family members and we are more or less mainlanders in some sense (Chan, 2018).

"Clashes of opposing political ideologies" are a primary cause of tension between Chinese Hongkongers and mainlanders (Yu \& Zhang, 2016, 8). For example, many students come from the mainland to attend universities in Hong Kong and are surprised by Hongkongers' political opinions. One student from the mainland explained that her secondary school teachers told her that Hong Kong was part of China. When she arrived in Hong Kong, though, she heard local students discussing the differences between Hong Kong and China. The implication was that China and Hong Kong are different countries, not temporarily separated parts of the same country. The mainland student called this attitude "unacceptable",

because Hong Kong is an inalienable part of China, so I would argue with them when they say so. Before coming to Hong Kong, I identified myself as Chinese rather than mainland Chinese. Hong Kong and [the] mainland are not on an equal position because Hong Kong is just one of China's cities, whereas China is a country [my emphasis added] (Yu \& Zhang, 2016, 8).

Another mainland student said that differing political attitudes made Hong Kong seem "more foreign than a foreign country" (Yu \& Zhang, 2016, 8). In spite of sharing a common, ancient heritage, many Hongkongers would agree with the mainland student's opinion.

\section{Mainland Tourism}

Hong Kong is again part of China under the one-country, two systems framework, but there is still a border. Mainlanders must purchase an Exit-entry Permit (¥80) to visit Hong Kong. In spite of this, the city is one of the top destinations for outbound mainland tourists, in part, because of its proximity and a lower tax rate on consumer goods (Li, 2018). Mainlanders constituted three-fourths of Hong Kong's sixty million visitors in 2017 (Note 32), and they contributed thirty-five percent of the city's total retail sales (Hong Kong Remains, 2017). Many Hongkongers rely on mainlanders for their livelihood. Because of this reliance, Sophie He, the business editor of the China Daily Hong Kong (an English-language newspaper owned by the Communist Party of China), encouraged Hongkongers to, 
treat [mainland] visitors better - we can't afford not to.... Many of my friends who live in different mainland cities say they are reluctant to visit Hong Kong as they feel they will not be welcome here.... Think of those visitors as guests to our home and be nice to them. Don't be mad at the visitors in crowded shopping malls or the MTR [trains], try to be helpful and understanding, and make the visitors feel they are welcome in Hong Kong. ... Finally, there is no need for local media to play up any conflicts between visitors and local residents (He, 2017).

Recent research indicates Hongkongers appreciate the economic benefits of visiting mainland tourists, yet hold negative views about the "social-cultural and environmental" impact they have on the city's shopping, dining, and transportation (Piuchan, Chan \& Kaale, 2017).

The conflict between mainland visitors and Hong Kong residents reached a fevered pitch in 2015, as unusually large numbers of visitors crossed the border to purchase bulk quantities of baby formula and diapers, causing widespread shortages in Hong Kong's retail outlets along the territorial boundary. Parallel traders took the baby formula and diapers back to the mainland for resale at exorbitant prices. Angry Hongkongers protested along the border, yelling at Chinese shoppers "Go back home!" (Ng \& Chan, 2015) (Note 33).

Ethnic Chinese writers living outside China have posted a plethora of editorials and opinion-pieces on the internet complaining about mainland tourists and offering social and historical explanations for their behaviour when visiting other countries, or Hong Kong (Phneah, 2018; Wang, 2017) (Note 34). During recent years, China's National Tourism Administration received complaints that Chinese tourists had broken foreign laws and offended local customs, having a negative impact on the country's image. The complaints included misuse of public toilets, misuse of facilities intended for persons with disabilities, and littering (Zhou, 2015). This led the Beijing government to issue a proclamation to mainland citizens about proper and improper behaviour when traveling abroad, entitled "Guide to Civilised Tourism and Travel" (2014).

Many Hongkongers feeling their local culture slipping away find it easy to latch onto social differences with mainlanders, as a way of exerting their own identity. In his book Imagined Communities, historian Benedict Anderson analysed how national communities are social constructs (Anderson, 1991, pp. 6-7). Nations benefit from othering a portion of society, reinforcing to their own people how they should act by giving them a socially and morally superior model. When Hongkongers assume their own superiority in comparison to mainlanders, they repeat the practices of colonial entities. This was one of the key techniques of the HKFU's This is Hong Kong, for instance, which differentiated British citizens of Hong Kong from both the local Chinese community and mainlanders.

The Hong Kong Tourism Board ("HKTB") is the marketing arm of the city's tourism industry. Its principal task is promoting Hong Kong internationally as an attractive tourist and business destination. Some HKTB promotional campaigns are quite superficial. For example, the HKTB created the annual "Shopping Festival" from June-August to attract overnight mainlander visitors and underscore the city's image as a "consumer's paradise" (Ng, 2010, p. 91) (Figure 4). Other HKTB campaigns are more instructive, describing Hong Kong's identity, its special relationship with China, and the mutual benefits of economic cooperation. The HKTB's Meetings and Exhibitions promotion (2014) described Hong Kong as "China's most important international business city"; its "fortuitous location at China's southern tip" makes Hong Kong ideal base to connect with the nation's "high-growth markets". The advertisement continued,

As a Special Administrative Region of China, Hong Kong enjoys a highly active and cooperative business relationship with Mainland China, and is its leading conduit for foreign investment ... and its second-largest trading partner after the U.S. ... Hong Kong is not only the perfect base for businesses to enter the Chinese market, but its "East meets West" business culture provides an ideal platform for Chinese enterprises to expand into the international community (Meetings and Exhibitions Hong Kong, 2014).

Decades after the British colonial period ended, authorities still market Hong Kong as a gateway to the East (a gateway to China). Although political and social tensions are obstacles on the pathway to reunification, Hong Kong appears destined to represent a good place for the world to do business. This is an important part of the city's colonial legacy, and part of its current and future identities. 


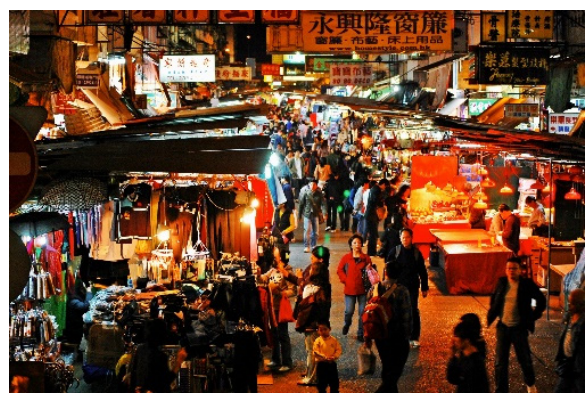

Figure 4. The Annual Shopping Festival in Hong Kong pxhere: Public Domain

\section{Conclusion}

Scholars have observed that globalization has caused certain East Asian cities to lose their Asian-ness. They have become somewhat bland, with a cultural "sameness" that ignores distinctive, local qualities (Logan, 2002, pp. vii-xiv). To avoid this fate, Hongkongers must embrace their city's special heritage and character, and find ways to distinguish Hong Kong from numerous, "anonymous urban metropolises" in East Asia and China (Chu \& Uebegang, 2002, 6). Hong Kong is certainly not just another Chinese city. Hongkongers struggle to define Hong Kong's identity because of its unique past and special entanglement with "modernity, coloniality and nationalism" (Chun, 2017).

The 1997 handover metaphorically returned an absent child (Hong Kong) from its foster parents (the British) to its birth parents (the Chinese) (Henry, 2007, 80). It has been a difficult homecoming because the foster parents and birth parents had different aspirations and philosophies. In addition, the one country, two systems policy allowed the child to continue living by the old foster parent's rules while residing in the birth parent's home. This is one reason why many Hongkongers are nostalgic for the past. Another reason is the increasingly inflexible posture taken by China's government authorities. When Hongkongers futility demanded that Beijing expand their voting rights during the well-publicized pro-democracy Umbrella Movement (2014), an impassive China responded, "What does the Motherland really owe you?" (Allen-Ebrahimian, 2014).

Ethnic Chinese constitute more than ninety percent of Hong Kong's population. Before the Second World War, the Chineseness of Chinese Hongkongers was relatively straightforward: Hong Kong was a cultural satellite of the neighbouring Guangdong province (Chun, 2017). Many residents therefore understood the British handover to China as a huí liú (回流, return back) to the zŭguó (祖国, motherland) (Cody, 2002, 185). In spite of one-hundred-fifty years of British rule, the key to resolving Hong Kong's current identity crisis will be resolving questions about the future. How will Hongkongers reconnect with Chinese society? How will Hongkongers adapt to China's rising national consciousness? What will Hong Kong's role be as China rises to prominence on the world stage? (Note 35).

This essay analyzed reflections of Hong Kong and the Hongkonger identity in various cultural arenas: the heritage industry, filmmaking, efforts to preserve built environment and intangible heritage, and tourism. Throughout Hong Kong's history, change seems to be the only constant (Note 36). The city has had many personalities: an idealized colony, a mainlander's refuge, a cultural mélange of the East and West, a Chinatown, a "consumer's paradise", a global business hub, and China's lost child. Hongkongers are still living in limbo, at the "intersection of different spaces" and cultures (Abbas, 1997, p. 4). In less than thirty years, the one country, two systems framework will end, and the Hong Kong-mainland political reunification will be complete. Perhaps by then Hong Kong will reconcile its complex past identities and its Chinese future.

\section{Acknowledgments}

This project was supported by a Hong Kong Baptist University Faculty Research Grant. I deeply appreciate the support of my Research Assistant, Andrianna Hughes.

\section{References}

Abbas, A. (1997). Hong Kong: Culture and the politics of disappearance. Hong Kong: Hong Kong University Press. 
Aitken, I., \& Ingham, M. (2014). Colonial film: The development of official film-making in Hong Kong, 194573, the Hong Kong Film Unit (1959-73) and This is Hong Kong (1961). Hong Kong documentary film (pp. 71-101). Edinburgh: Edinburgh University Press.

Allen-Ebrahimian, B. (2014, October 9). 'Hong Kong, what does the motherland really owe you?' Foreign Policy. https://foreignpolicy.com/2014/10/09/hong-kong-what-does-the-motherland-really-owe-you/

Amrith, M. (2014, June 10). Building city identities in contexts of diversity. New York: The United Nations University Institute on Globalization, Culture and Mobility. Retrieved from https://gcm.unu.edu/ publications/policy-reports/building-city-identities-in-contexts-of-diversity.html

Anderson, B. (1991). Imagined communities: Reflections on the origin and spread of nationalism. London: Verso.

Antiquities and Monuments Office. (2018). built heritage in Hong Kong. http://www.amo.gov.hk/en/built.php

Antiquities and Monuments Office. (2018). Three historic buildings at old Lei Yue Mun Barracks declared monuments (with photos). http://www.amo.gov.hk/en/whatsnew_20160520.php

Ashworth, G. (2011). Preservation, conservation and heritage: Approaches to the past in the present through the built environment. Asian Anthropology, 10(1), pp. 1-18.

Bowman, P. (2008, April 22). The symbolic structure of Game of Death. Martial Arts Studies. Retrieved from http://martialartsstudies.blogspot.com/2008/04/symbolic-structure-of-game-of-death.html\#!/2008/04/symbo lic-structure-of-game-of-death.html

Bowman, P. (2009). Theorizing Bruce Lee: film-fantasy-fighting-philosophy. Amsterdam: Rodopi.

Bray, M., \& Lee, W. O. (1993). Education, democracy and colonial transition: The case of Hong Kong. International Review of Education, 39(6), 541-60. Retrieved from http://www.jstor.org.lib-ezproxy. hkbu.edu.hk/stable/3444980

Carroll, J. (2007). A concise history of Hong Kong. Hong Kong: Hong Kong University Press.

Chan, A. (2018, March 1). Hongkongers who look at mainlanders with disdain need to recall their own roots. South China Morning Post. Retrieved from http://www.scmp.com/comment/letters/article/2135259/ hongkongers-who-look-mainlanders-disdain-need-recall-their-own-roots

Cheung, G. (2012, October 1). Beijing finds Hongkongers' nostalgia for colonial era hard to fathom. South China Morning Post. Retrieved from http://www.scmp.com/news/hong-kong/article/1051035/beijing-finds -hongkongers-nostalgia-colonial-era-hard-fathom

Chinese Cultural Studies Center. (2018). Intangible cultural heritage in China. Retrieved from https://www.culturalheritagechina.org/

Chu, C., \& Uebegang, K. (2002). Saving Hong Kong's cultural heritage. Hong Kong: Civic Exchange. Retrieved from http://www.google.com.hk/url? $\mathrm{sa}=\mathrm{t} \& \mathrm{rct}=\mathrm{j} \& \mathrm{q}=\& \mathrm{esrc}=\mathrm{s} \&$ source $=$ web $\& \mathrm{~cd}=6 \& \mathrm{cad}=\mathrm{rja} \&$ uact $=8 \& \mathrm{ved}=0$ ahUKEwjp5s2tg-vaAhXFxrwKHRfKCusQFghNMAU\&url=http\%3A\%2F\%2Fcivic-exchange.org\%2Fwpcontent $\% 2$ Fuploads $\% 2$ F2002\%2F02\%2F18-200202ART_SavingCulturalHeritage_en.pdf\&usg=AOvVaw3 VRwgmbO2k8PJaXnxiKFEZ

Chun, A. (2017, June 15). Why should we care about chineseness? 21st Century Global Dynamics: global-e, 10(40). Retrieved from http://www.21 global.ucsb.edu/global-e/june-2017/why-should-we-care-about -chineseness

Chun, A. (2018). Forget chineseness: On the geopolitics of cultural identification. Albany: State University of New York Press.

Cody, J. (2002). Heritage as hologram: Hong Kong after a change in sovereignty, 1997-2001. In W. Logan (Ed.), The disappearing 'Asian' city: Protecting Asia's urban heritage in a globalizing world (pp. 185-207). Oxford: Oxford University Press.

Dahl, M. (2016). The little-known medical history of homesickness. New York Magazine. Retrieved from https://www.thecut.com/2016/02/homesickness-was-once-considered-a-medical-diagnosis.html

Dapiran, A. (2017, December). Hong Kong nostalgia: sickness or cure? Cha: Writing Hong Kong. Retrieved from http://www.asiancha.com/content/view/2899/646/

Eco, U. (1986). The city of robots. Travels in hyperreality. Orlando: Harcourt, Brace Javonovic. 
Ellis, J. (2017). "You can live like a king ...": A postcolonial tour of colonial Hong Kong. Journal of Asian and African Studies, 26(2), 209-32.

Erni, J. (1998). Like a culture: Notes on pop music and popular sensibility in decolonized Hong Kong. Hong Kong Cultural Studies Bulletin. Spring/Summer, 57-61.

Foster, P. (2007). The geopolitics of Kung Fu film. China Research Center, Post Series, 6(2). Retrieved from https://www.chinacenter.net/2007/china_currents/6-2/the-geopolitics-of-kung-fu-film/

Grace, H. (2007). Monuments and the face of time: distortions of scale and asynchrony in postcolonial Hong Kong. Postcolonial Studies, 10(4), 467-483.

Harrison, R. (Ed.). (2010). Understanding the politics of heritage. Manchester: Manchester University Press in Association with the Open University.

He, S. (2017). To make the most of rebound in tourist arrivals, Hong Kong must treat visitors better. Straits Times. Retrieved from https://www.straitstimes.com/asia/east-asia/to-make-the-most-of-rebound-in-tourist -arrivals-hong-kong-must-treat-visitors-better

Hendry, J. (2016). An anthropological lifetime in Japan: The writings of Joy Hendry. Leiden: Brill.

Henry, G. (2007). Art and culture: Hong Kong or the creation of a collective memory. China Perspectives, 2007(2), 79-86.

Hong Kong residents, mainland people have similarities - and also big differences (2016, November 12). South China Morning Post. Retrieved from http://www.scmp.com/news/hong-kong/education-community/ article/2045245/hong-kong-residents-mainland-people-have

Hong Kong's July 1 March turnout hits three-year low, estimated at 50,000. (2018, July 1). South China Morning Post. Retrieved from https://www.scmp.com/news/hong-kong/politics/article/2153284/hong -kongs-july-1-march-kicks-controversy-over-police-orders

Hong Kong remains a vibrant retail opportunity for mainland China. (2017, February 22). Nielson Hong Kong. Retrieved from http://www.nielsen.com/hk/en/insights/news/2017/hong-kong-remains-a-vibrant-retail -opportunity-for-mainland-chinese-travelers.html

How Britain said farewell to its empire. (2010, July 23). BBC News. Retrieved from http://www.bbc.com/ news/magazine-10740852

In Pictures: Better times? Hong Kong's British nostalgia trip. (2017, May 28). Hong Kong Free Press. Retrieved from https://www.hongkongfp.com/2017/05/28/pictures-better-times-hong-kongs-british-nostalgia-trip/

Intangible Cultural Heritage Office. (2018). Retrieved from https://www.lcsd.gov.hk/CE/Museum/ICHO/ en_US/web/icho/the_representative_list_of_hkich.html

Kan, F., \& Vickers, E. (2002). One Hong Kong, two histories: "History" and "Chinese History" in the Hong Kong school curriculum. Pre-published version. Retrieved from https://hub.hku.hk/bitstream/10722/48575/ 1/67160.pdf?accept=1

Kato, M. T. (2005). Burning Asia: Bruce Lee's kinetic narrative of decolonization. Modern Chinese Literature and Culture, 17(1), 62-99.

Klein, D. (2018). David Klein: Original travel art. Retrieved from http://www.davidkleinart.com/Original _Travel_Poster_Art.html\#38

Lai, A. (2012, July 30). 'National education' raises furor in Hong Kong. CNN. Retrieved from https://edition.cnn.com/2012/07/30/world/asia/hong-kong-national-education-controversy/index.html

Lhatoo, Y. (2015, July 31). Why does Hong Kong treat Bruce Lee like an outcast and refuse to honour its greatest son? South China Morning Post. Retrieved from http://www.scmp.com/comment/insight-opinion/ article/1845229/why-does-hong-kong-treat-bruce-lee-outcast-and-refuse-honour

Li, J. (2018, January 3). Chinese tourists still favour Hong Kong for travel during new year break. South China Morning Post. Retrieved from http://www.scmp.com/business/china-business/article/2126647/hong-kong -still-firm-favourite-among-chinese-tourists-ring

Lin, J. (2011). Demystifying the Chinese economy. Cambridge: Cambridge University Press.

Liu, J. (2012, September 1). Hong Kong debates 'national education' classes. BBC. Retrieved from https://www.bbc.com/news/world-asia-china-19407425 
Logan, W. (2002). Introduction: Globalization, cultural identity, and heritage. In W. Logan (Ed.), The disappearing 'Asian' city: Protecting Asia's urban heritage in a globalizing world (pp. xii-xxi). Oxford: Oxford University Press.

Lucado, M. (2012). Grace: More than we deserve, greater than we imagine. Nashville, TN: Thomas Nelson.

Meetings and Exhibitions Hong Kong. (2014). Retrieved from https://www.mehongkong.com/eng/why-hong -kong/gateway-to-china.html

Moody, J. (2015) Heritage and history. In E. Waterton, \& S. Watson (Eds.), The Palgrave handbook of contemporary heritage research (pp. 113-129). London: Palgrave Macmillan.

Ng, J. (2010). Paradigm city: Space, culture, and capitalism in Hong Kong. Albany, NY: State University of New York Press.

Ng, K. C. (2018, April 30). Hong Kong visitor numbers continue to rise, with 5 million tourists in ...March. South China Morning Post. Retrieved from https://www.scmp.com/news/hong-kong/hong-kong-economy/ article/2144090/hong-kong-visitor-numbers-continue-rise-5-million

Ng, N., \& Chan, W. (2015, March 4). Hong Kong to Chinese shoppers: 'Go home'. CNN. Retrieved from https://edition.cnn.com/2015/03/03/china/hong-kong-china-conflict/index.html

Nicolson, K. (2016). Landscapes lost and found: Appreciating Hong Kong's heritage cultural landscapes. Hong Kong: Hong Kong University Press.

Pang, J. (2017, August 6). In pictures: Demonstrations and demolition - 10 years since the Queen's Pier was pulled down. Hong Kong Free Press. Retrieved from https://www.hongkongfp.com/2017/08/06/ pictures-demonstrations-demolition-10-years-since-queens-pier-pulled/

Phneah, J. (2018). 5 reasons why Chinese tourists are so rude. Jeraldine (blog). Retrieved from http://www.jeraldinephneah.com/5-reasons-why-chinese-tourists-are-so-rude/

Piuchan, M., Chan, C. W., \& Kaale, J. (2017). Economic and socio-cultural impacts of mainland Chinese tourists on Hong Kong residents. Kasetsart Journal of Social Sciences, 39(1), 9-14. Retrieved from https://www.sciencedirect.com/science/article/pii/S2452315117306136

Policy Address of the Chief Executive of Hong Kong, Mr. Tung Chee Hwa. (1997).

Policy Address of the Chief Executive of Hong Kong, Mr. Tung Chee Hwa. (1999). paragraphs 133 and 164.

Poynter, M. (1921). Around the shores of Asia. London: George Allen \& Unwin Ltd.

Prentice, R. (1993). Tourism and heritage attractions. New York: Routledge.

Qian, Y. (2017). How reform worked in China: The transition from plan to market. Cambridge: MIT Press.

Rayfield, D. (1997). Anton Chekhov: A life. Chicago: Northwestern University Press.

Ross, P. (2015, September 21). Memories are made of this: How nostalgia for Hong Kong's trams, neon signs and other physical landmarks creates a sense of identity. South China Morning Post. Retrieved from http://www.scmp.com/comment/insight-opinion/article/1860144/memories-are-made-how-nostalgia-hong-k ongs-trams-neon-signs

Said, E. (1978). Orientalism. London: Pantheon.

Sedikides, C., Wildschut, T., Routledge, C., \& Arndt, J. (2015, February). Nostalgia counteracts selfdiscontinuity and restores self-continuity. European Journal of Social Psychology, 45(1), 52-61.

Sharp, M. (2013, October 13). What colonial symbols might they target after Hong Kong's royal postboxes? South China Morning Post. Retrieved from http://www.scmp.com/lifestyle/article/1866866/ what-colonial-symbols-might-they-target-after-hong-kongs-royal-postboxes

Smith, O. (2017, August 31). Mapped: The world's most overcrowded cities. The Telegraph. Retrieved from https://www.telegraph.co.uk/travel/lists/most-overcrowded-cities-in-the-world/

Springer, K. (2016, October 6). Hong Kong's urban explorers. BBC. Retrieved from http://www.bbc.com/travel/story/20160930-hong-kongs-urban-explorers

The danger of historical amnesia: A conversation with writer David McCullough. (2002, July/August) Humanities: The Magazine of the National Endowment for the Humanities (July/August 2002). Retrieved from https://www.neh.gov/humanities/2002/julyaugust/conversation/the-danger-historical-amnesia 
Tierney, J. (2013, July 8). What is nostalgia good for? Quite a bit, research shows. The New York Times. Retrieved from https://www.nytimes.com/2013/07/09/science/what-is-nostalgia-good-for-quite-a-bit-research-shows.html

Tomlinson, P. (2016, October 12). Haw Par Mansion: 1930's splendour given new lease of life as music academy. South China Morning Post. Retrieved from http://www.scmp.com/property/article/2026962/ haw-par-mansion-1930s-splendour-given-new-lease-life-music-academy

Tourism Commission. (2018). Tourism performance. Retrieved from www.tourism.gov.hk/english/statistics/ statistics_perform.html

Trading Economics. (2018). Retrieved from https://tradingeconomics.com/hong-kong/gdp

Tsang, S. (2007). A modern history of Hong Kong. New York: I.B. Tauris.

Turner, M. (1995). Introduction and 60's/90's: Dissolving the people. In M. Turner \& I. Ngan (Eds.), Hong Kong sixties: Designing identity (pp. i-xvi and 1-30). Hong Kong: Hong Kong Arts Centre.

Turton, S. (2018, March 29). Old but not old enough: Architecture advocates worried post-war buildings will disappear. Coconuts Hong Kong. Retrieved from https://coconuts.co/hongkong/features/old-not-old-enough -architecture-advocates-worried-post-war-buildings-will-disappear/

UNESCO. (2018). What is Intangible Cultural Heritage? Retrieved from https://ich.unesco.org/en/what-is -intangible-heritage-00003

Wallis, K. (2011, June 6). Bruce Lee: representative of Chinese nationalism and masculinity? Word Press. Retrieved from https://ethnographerapprentice.wordpress.com/2011/06/06/bruce-lee-representative-of -chinese -nationalism-and-masculinity/

Wang, P. (2017, April 30). Why you shouldn't look down your nose at Chinese tour groups. Hong Kong Free Press. Retrieved from https://www.hongkongfp.com/2017/04/30/shouldnt-look-nose-chinese-tour-groups/

Wei, B., \& Li, E. (1998). Culture shock! Hong Kong. London: Kuperard.

White, B. (1996). Hong Kong: Somewhere between heaven and earth. Oxford: Oxford University Press.

Wong, B. (2013). Introduction. In B. Wong \& C.B. Tan (Eds.), Chinatowns around the world: Gilded ghetto, ethnopolis, and cultural diaspora. Leiden: Brill.

Xue, C. (2016). Hong Kong architecture 1945-2015: From colonial to global. New York: Springer.

Yip, A. (2015, July 19). How Bruce Lee made it "cool" to be Chinese growing up in America. South China Morning Post. Retrieved from http://www.scmp.com/news/hong-kong/article/1841187/how-bruce-lee-made -it-cool-be-chinese-growing-america

Yu, B., \& Zhang, K. (2016). 'It's more foreign than a foreign country': adaptation and experience of mainland Chinese students in Hong Kong. Tertiary Education and Management. http://dx.doi.org/10.1080/ 13583883.2016.1226944

Zhao, L., \& Cohen, W. (1997). Hong Kong under Chinese rule: the economic and political implications of reversion. Cambridge: Cambridge University Press.

Zhou, S. (2015, April 28). New standard of behavior to promote 'civilized' tourism. China Daily. Retrieved from http://www.chinadaily.com.cn/china/2015-04/28/content_20563642.htm

\section{Notes}

Note 1. Hongkongers have held civil rights protests each year on the first day of July since the transfer of Hong Kong's sovereignty from the United Kingdom to China on 1 July 1997. Hundreds of thousands attended the 2012 protest, which was held on the fifteenth anniversary of the handover. Turnout for the annual protest has declined considerably over recent years, hitting an all-time low in 2018 ("Hong Kong's July 1 march", 2018).

Note 2. There is a lively, longstanding debate over which event, or set of events, signaled the end of the British Empire ("How Britain said farewell", 2010).

Note 3. Melissa Dahl offered an interesting, non-specialist perspective on nostalgia (Dahl, 2016).

Note 4. In this essay Hong Kong is referred to as a city, as is commonly done in the popular press and mainstream media. However, Hong Kong is a Special Administrative Region of the People's Republic of China, and is often described as a region or territory. 
Note 5. Children have few memories, so they construct positive fantasies to imagine the past. Fantasies are an important part of pretend play, when a young person acts as if an imaginary set of conditions exists and then creates a situation where something unreal becomes real.

Note 6. Janet $\mathrm{Ng}$ discussed the phenomenon of nostalgically longing for the "likely world" of a lost Old Hong Kong (Ng, 2010, p. 51).

Note 7. Richard Prentice warned against defining heritage solely as "something which is passed from one generation [stressing only its heterogeneity. Because that] ignores the way we as individuals each become aware of 'our' heritage, and claim it, emotively as inspiration, comfort, or possession." (Prentice, 1993, p. xiii).

Note 8. The collaborative online resource, Gwulo: Old Hong Kong (https://gwulo.com) has well over 30,000 pages devoted to research and documentation concerning Hong Kong's colonial past. Gwulo (古老') translates roughly as old-fashioned.

Note 9. Eco describes visiting Disneyland and taking a make-believe river cruise through a man-made jungle, populated by robotic crocodiles and other harmless creatures. According to tourism scholar Richard Prentice, many "heritage tourists" lack the capacity for differentiating the authentic and contrived and many people enjoy being fooled_as part of the tourist experience (Prentice, 1993, p 43).

Note 10. Tourism products, over time, come to define a location's heritage for many tourists (Prentice, 1993, pp. 5-10).

Note 11. One urban explorer said his mission was "immortalising these sites that are fast disappearing in our city. It's a form of preservation, really, [of] negative spaces - the spaces that exist in limbo" (Springer, 2016).

Note 12. Although it implies so much more, "belonger status" is a legal category associated with a person living in a British Overseas Territory who is either native-born or has been granted the status of a native-born resident. In Hong Kong, permanent residents enjoy the special rights of belongers, including the right to work without special permits and the right of abode within the territory.

Note 13. Even today, many ethnic Chinese residents of Hong Kong do not consider the city to be their permanent or ancestral home. They may pass on a Chinese heritage to their descendants, but it does not specifically involve Hong Kong (Cody, 2002, p. 193).

Note 14. Europeans created the problematic concept of the Orient to describe Asia. Europeans contrasted the Occident, of the West, with the Orient, of the East. The influential postcolonial writer Edward Said described European's conception of the Orient as "a place of romance, exotic beings, haunting memories, landscapes, [and] remarkable experiences". "European culture gained in strength and identity by setting itself off against the exotic Orient", wrote Said. Orientalism was a potent means to justify colonialism and a powerful tool used to develop ethnography and the travel trade (Said, 1978, pp. 9-11).

Note 15. The Republic of China ("ROC") was established on the mainland in 1912. The ROC lost the Chinese Civil War and control of the mainland to the PRC, and then fled to Taiwan in 1949, still claiming to be the legitimate government of China.

Note 16. Since the nineteenth century, the terms Hongkonger and Hong Kongese have been used to refer to people from Hong Kong, regardless of ethnicity. During the colonial era, people were also distinguished as Hong Kong Chinese or Hong Kong Britons.

Note 17. Government-sponsored travel slogans reveal a nation's self-identity. "Malaysia Truly Asia”, for example, emphasizes the Southeast Asian nation's diversity and multiculturalism. "Taiwan: The Heart of Asia" stresses the warmth and friendliness of its residents.

Note 18. Academics have effectively combined postcolonial theory with the field of film studies. Each involves power relations, representations of the Other, and cultural conflicts. Otherness is addressed in many scholarly discourses, including philosophy (by Georg Wilhelm Friedrich Hegel, and others), psychology (Jacques Lacan), post colonialism (Homi Bhabha), and gender studies (Simone de Beauvoir).

Note 19. Many East Asian nations gained independence from European powers after the Second World War: from the United Kingdom: Burma (1948), Malaya (1957), and Singapore (1963); from France: Vietnam (1945), Cambodia (1953), and Laos (1953); from the Netherlands: Indonesia (1945); from the United States: the Philippines (1946).

Note 20. Hong Kong conservationists have recently stressed the importance of preserving significant structures built after the Second World War (Turton, 2018; Xue, 2016). 
Note 21. Lei Yue Mun is a narrow strait separating Hong Kong Island from Kowloon peninsula. The strait is strategically important because it connects Victoria Harbour to the South China Sea. The barracks were part of a British Army defense compound that oversaw the strait and protected Hong Kong Island from the area of Kowloon controlled by China. The entire Kowloon peninsula came under British control when China ceded the New Territories in 1897. The AMO evaluators did not seem concerned that the barracks housed an occupying military force (Antiquities and Monuments Office, 2018, Three historic buildings).

Note 22. The fourth emperor of the Qing dynasty, Kangxi (康熙, reign 1662-1722) built Tung Lung Fort to protect Tung Lung Chau Island from pirates. The fifth emperor of the Qing dynasty, Yongzheng (雍正, reign 1722-35) built Fan Lau Fort to protect Lantau Island from pirates traveling through the Pearl River estuary. Tung Chung Fort was the naval headquarters of the Right Battalion of Mirs Bay (Dapeng), also on Lantau Island, and guarded the main sea passage to Canton (Guangzhou).

Note 23. Hong Kong's government announced a new heritage preservation policy in 2007. The emphasis is now on providing incentives to private owners and non-profit organizations to adapt historic buildings for reuse as social enterprises.

Note 24. Self-reflection pervaded Chinese society during China's Republican era (1912-49). After the Qing dynasty's downfall in 1912, a new generation of Chinese architects sought to revitalize architecture on the mainland, Taiwan, and Hong Kong and nationalize Chinese architecture. The new architects studied both classical Chinese designs and modern construction technology and developed a Chinese Renaissance style. In Hong Kong, architects used the new style most effectively in Christian churches and in private estates, such as Haw Par Mansion.

Note 25. Aw Boon Haw worried that Chinese Hongkongers, living in a British colony, were losing their traditional cultural identity. He used Tiger Balm Park's sculptures and decorations to illustrate and promote Buddhist, Taoist, and Confucian stories and messages (Nicolson, 2016).

Note 26. The seven-story Tiger Pagoda was one of the tallest structures in Hong Kong when it was built.

Note 27. Hong Niang (红娘) is a hua dan character in the classic Yuan dynasty love story Romance of the West Chamber (西廂记). Romance of the West Chamber was controversial because it told the story of a young couple who consummated their love without parental approval.

Note 28. U.S. President, Franklin Roosevelt had previously suggested that Hong Kong would return to Chinese control, under Chiang Kai-shek (Zhao \& Cohen, 1997).

Note 29. Between 1960 and 2016, Hong Kong's Gross Domestic Product (GDP), a measurement of national income and output, increased from 1.32 USD Billion to 320.91 USD Billion. Hong Kong's GDP value now represents 0.52 percent of the world economy (Trading Economics, 2018).

Note 30. Confucianism, an ancient Chinese philosophy, had a great historical influence on each of the Asian Tigers (as well as the economic powerhouse Japan). This led some economists to theorize that the Tigers' successes was attributable to Confucian culture, which stresses diligence, frugality, willingness to save and invest, and deference to authority. Influential Chinese economist, Justin Yifu Lin, however, has pointed out that if Confucian culture were responsible, then China would have also found economic success during the same period, which it did not (Lin, 2011, p. 107). Most economists give credit for China's economic rise to liberalization and the opening of its economy to global markets, not to Confucian principles (Qian, 2017).

Note 31. On 20 May 2006, China's Ministry of Culture released The National List of Intangible Cultural Heritage of China, which included 518 items. The current national list, as well as provincial, special regional (including Hong Kong), and national central city lists are available online (Chinese Cultural Studies Center, 2018).

Note 32. Hong Kong is also a popular destination for tourists from Taiwan, South Korea, Japan, the United States, Macao, the Philippines, Singapore, Australia, and Thailand (Tourism Commission, 2018).

Note 33. Anti-mainland protests caused the number of Chinese visitors to Hong Kong to drop dramatically, though the Hong Kong Tourism Board reported that the numbers had rebounded by the end of 2017 (Ng, 2018).

Note 34. The popular online news source Coconuts Hong Kong has an entire section called "Mainland Follies", featuring stories about mainlander visitors in Hong Kong (https://coconuts.co/hongkong/).

Note 35. Allen Chun argued convincingly that there is no single Chinese cultural identity (no single Chineseness), but, rather, various Chinese identities produced by different geopolitical and economic factors (Chun, 2018). 
Note 36. Historians credit the Greek philosopher Heraclitus with the famous aphorism "change is the only constant in life."

\section{Copyrights}

Copyright for this article is retained by the author(s), with first publication rights granted to the journal.

This is an open-access article distributed under the terms and conditions of the Creative Commons Attribution license (http://creativecommons.org/licenses/by/4.0/). 